\title{
Cholelithiasis with atrophy of the right lateral hepatic lobe in a horse
}

\author{
Colelitíase com atrofia do lobo lateral direito em um cavalo
}

\author{
Renato de Lima Santos ${ }^{I *}$ Tatiane de Fátima Brandão de Oliveira ${ }^{\mathrm{I}}$ \\ Taismara Simas de OliveiraI João Felipe Brito Galvão ${ }^{I}$ \\ Tatiane Alves da Paixão ${ }^{I}$ Barbara Goloubeff ${ }^{2}$
}

\section{ABSTRACT}

A 22 year-old horse developed cholelithiasis with marked atrophy of the right lateral hepatic lobe. The horse had a history of intermittent colic since three years of age, and one of the first episodes of colic was associated with icterus. The size of the right lateral hepatic lobe was extremely reduced. There was a large choledocholith in the common hepatic duct, and several hepatoliths and choleliths in the intra- and extra-hepatic billiary ducts. Microscopically, there was severe atrophy of the right lobe with diffuse proliferation of connective tissue and billiary ducts. The left lateral lobe had peri-portal fibrosis with proliferation of billiary ducts, and billiary stasis. Chemical analysis of the calculi detected amorphous and triple phosphate, bilirubin, calcium, and iron.
\end{abstract}

- NOTE
Key words: horse, cholelithiasis, biliary calculi, biliary obstruction, liver, hepatic atrophy.

\section{RESUMO}

Um cavalo de 22 anos de idade desenvolveu quadro de colelitíase severa com atrofia do lobo lateral direito. O animal tinha histórico de cólica recorrente, desde os três anos de idade, sendo que um dos primeiros episódios de cólica foi acompanhado de icterícia. O lobo hepático lateral direito estava extremamente diminuído de volume. Havia um grande coledocólito localizado no ducto hepático comum e inúmeros hepatólitos e colélitos nos ductos biliares intra e extrahepáticos. Microscopicamente, foi observada atrofia acentuada do lobo direito, com proliferação difusa de tecido conjuntivo fibroso e de ductos biliares. O lobo lateral esquerdo apresentava fibrose periportal difusa associada à proliferação acentuada de ductos biliares e estase biliar. Análise química das concreções detectou fosfato triplo e amorfo, bilirrubina, cálcio e ferro.
Palavras-chave: eqüino, colelitíase, cálculo biliar, obstrução biliar, fígado, atrofia hepática.

Cholelithiasis is a general term to describe the condition in which calculus is formed in the biliary tract. These processes can be further divided into: (i) calculi located in the intra-hepatic biliary tract, which are named hepatoliths; (ii) calculi located in the extrahepatic biliary ducts are named choleliths; and (iii) calculi located in the common hepatic duct, described as choledocholiths (SCHNEIDER, 1997). Occurrence of biliary calculi in horses is relatively rare with an estimated prevalence of 0.08\% (SCHNEIDER, 1997). Age has been identified as the only significant individual risk factor for cholelithiasis. The risk for biliary calculi increases with age, and generally most of the affected horses are over nine years of age (JOHNSTON et al., 1989; REEF et al., 1990).

Several causes or predisposing factors have been identified, including foreign bodies, such as wooden sticks (GERROS et al., 1993), and ascending bacterial infections (PEEK \& DIVERS, 2000), with Escherichia coli, Aeromonas sp., Citrobacter sp., Salmonella sp., group D Streptococcus sp., and other gram-negative bacteria being often isolated in cases of cholelithiasis in horses (JOHNSTON et al., 1989; MOENS, 1990; REEF et al., 1990).

IEscola de Veterinária, Universidade Federal de Minas Gerais (UFMG), Departamento de Clínica e Cirurgia Veterinárias. Av. Antônio Carlos, 6627, 31270-901. Belo Horizonte, MG, Brasil. E-mail: rsantos@vet.ufmg.br. Autor para correspondência.

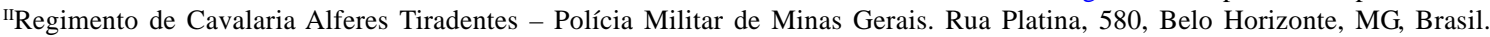


Cholelithiasis in horses may cause no clinical signs or may be associated with signs of biliary obstruction and recurrent abdominal pain (TRAUB et al., 1982; VAN DER LUER \& KRONEMAN, 1982; TRAUB et al., 1983). Biliary obstruction due to cholelithiasis may result in neurological changes due to hepatic encephalopathy (PEEK \& DIVERS, 2000; FERNANDES et al., 2001). A presumptive diagnosis is based on clinical signs, and a final diagnosis is usually based on exploratory laparotomy or necropsy (TRAUB et al., 1982; VAN DER LUER \& KRONEMAN, 1982; TRAUB et al., 1983, FERNANDES et al., 2001). However, ultrasonography allows a non-invasive and accurate diagnosis (REEF et al., 1990).

Here we describe a case of cholelitiasis in a 22-year-old crossbred horse euthanatized due to iatrogenic rupture of the rectum. The horse had a history of intermittent colic since three years of age, with a total of 20 occurrences of clinically significant colic in addition to several episodes of mild abdominal pain. One of the first clinical manifestations of colic when the horse was 3 years old was associated with icterus. The horse had abdominal pain for 24 hours prior to admission at the Veterinary Hospital. Upon admission the horse had a mild yellowish mucosal discoloration, associated with mild anemia (4.84 x $10^{6}$ erythrocytes per $\mathrm{mm}^{3}$, and $9.7 \mathrm{~g}$ of hemoglobin per $\mathrm{dL}$ ), with all the other blood cells within the reference values. Twenty-four hours after admission, examination of the peritoneal fluid indicated a total protein concentration of $3.8 \mathrm{~g} \mathrm{dL}^{-1}$, 140,000 erythrocytes and 84,000 nucleated cells per $\mathrm{mm}^{3}$. In the next day, these values increased to $5.2 \mathrm{~g}$ $\mathrm{dL}^{-1}, 260,000$ erythrocytes and 173,100 nucleated cells per $\mathrm{mm}^{3}$, indicating an acute peritonitis. Due to the poor prognosis the horse was then submitted to euthanasia.

At necropsy, oral and conjunctival mucosas as well as the carcass were mildly icteric. There was a complete rupture of the rectal wall of approximately $10 \mathrm{~cm}$ in diameter associated with a diffuse fibrinous peritonitis. The right lateral hepatic lobe was extremely decreased in size measuring approximately 23 by $11 \mathrm{~cm}$, and no more than $1 \mathrm{~cm}$ thick (Figure 1). In sharp contrast, the left lateral and medial lobes were markedly increased in size. The liver had a diffuse brownish discoloration, was firm, and an evident lobular pattern was observed on the cutting surface. A large choledocholith measuring $9.5 \times 4.5 \mathrm{~cm}$, with smooth surface was found in the common hepatic duct, which was apparently completely obstructed. Numerous choleliths and hepatoliths, moderately firm, ranging from 1.5 to $0.1 \mathrm{~cm}$ in diameter, were located in virtually all intra- and extra-hepatic biliary ducts (Figure 1), which were markedly dilated (Figure 2). The largest choledocholith that was obstructing the common hepatic duct had a dry weight of $141.72 \mathrm{~g}$, whereas all the other biliary calculi extracted from the liver and

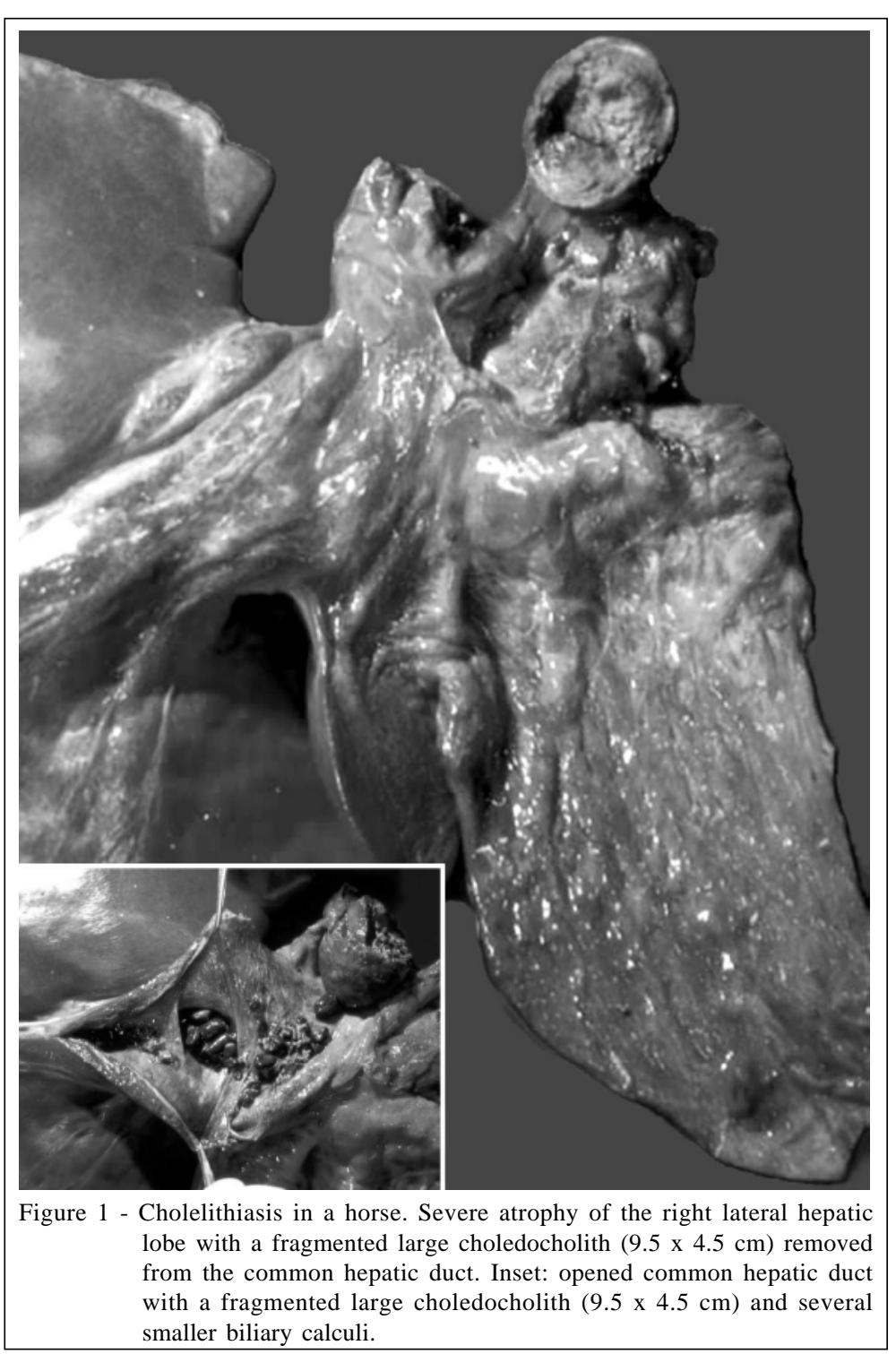

Ciência Rural, v.37, n.2, mar-abr, 2007. 


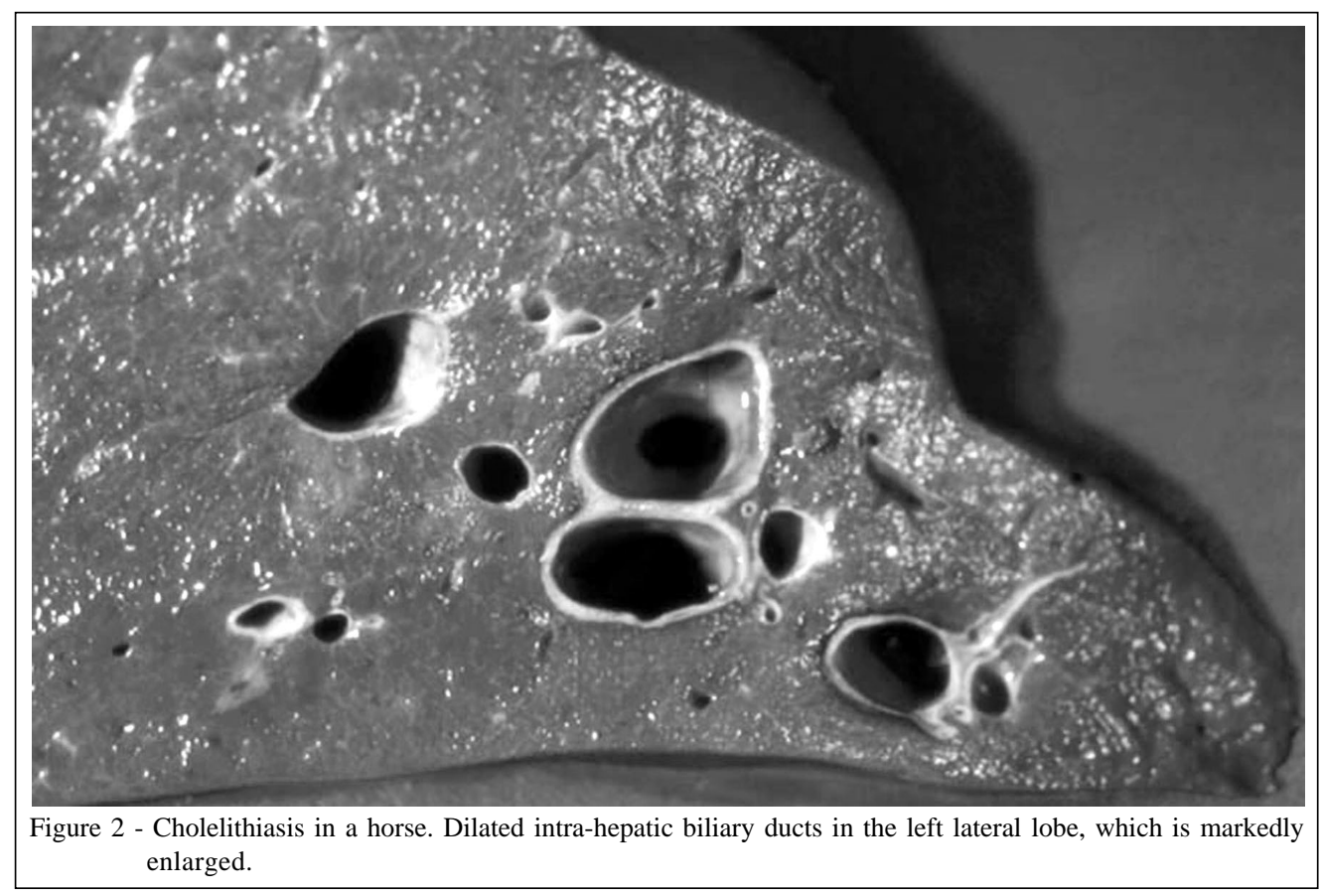

extra-hepatic biliary ducts had a dry weight of $98.92 \mathrm{~g}$ all together, and more than 1,120 choleliths were counted. No other intestinal or abdominal lesions that could be accounted for the history of abdominal pain were observed. Histologically, a severe atrophy of the right lobe was observed, which was characterized by an almost complete replacement of the normal hepatic parenchyma by fibrous connective tissue and proliferating bile ductules. Sections of the left lateral lobe had a moderate to severe diffuse peri-portal fibrosis associated with a marked proliferation of biliary ductules, and biliary stasis.

Qualitative chemical analysis of the largest choledocholith detected amorphous and triple phosphate, calcium, and iron, but absence of biliary pigments and cholesterol. One representative hepatolith was also chemically analyzed, and bilirubin was detected in addition to the elements detected in the largest choledocholith.

The only significant clinical sign observed in this case was abdominal pain. Importantly, the horse had signs of colic prior to any rectal examination and therefore prior to the rectal rupture. Considering that in addition to cholelithiasis no other significant intestinal or abdominal lesion was observed, it is reasonable to assume that the abdominal pain in this case was due to the hepatic and biliary lesions. This is in good agreement with the previous reports that list colic as the primary clinical manifestation in cases of cholelithiasis (VAN DER LUER \& KRONEMAN, 1982;
TRAUB et al., 1982; JOHNSTON et al., 1989; PEEK \& DIVERS, 2000). The age in this case is a good example for the predisposition of the disease to affect horses over nine years of age (JOHNSTON et al., 1989, REEF et al., 1990). However, one of the first clinical manifestations of colic in this case when the horse was 3 years old was associated with icterus, which may suggest that although diagnosed at an advanced age the disease may have initiated much earlier.

As observed here, most of the cases of cholelithiasis in horses are associated with multiple choleliths (JOHNSTON et al., 1989), although an extremely high number of choleliths such as described in this case could be considered unusual. Most of the reported cases of cholelithiasis are associated with enlargement of the liver (REEF et al., 1990; JOHNSTON et al., 1989), in spite of a few cases in which the liver may be diffusely contracted due to proliferation of connective tissue (TRAUB et al., 1982). However, a marked atrophy of a particular hepatic lobe as observed in this case is not a frequent finding, with only one previous report of a similar lesion (MOENS, 1990). The gross and histological findings clearly indicate a very chronic condition since abundant fibrosis developed diffusely in the liver, particularly in the right severely atrophied hepatic lobe.

The chemical composition of the calculi in this case is in good agreement with the previous reports. Most of the biliary calculi in horses contain high concentrations of calcium bilirubinate, with a few having 
a predominance of calcium phosphate, whereas cholesterol concentration is usually low (JOHNSTON et al., 1989; SCHNEIDER, 1997). Interestingly, the largest choledocholith that obstructed the common hepatic duct in this case was composed of phosphates with neither biliary pigments nor cholesterol, which is similar to the only previously described case of lobular atrophy in which the obstructing choledocholith was also composed of phosphates (MOENS, 1990).

Based on the pathological findings a diagnosis of intra- and extra-hepatic cholelithiasis associated with severe atrophy of the right hepatic lobe was made. Apparently, biliary calculi associated with atrophy of the right lobe is a rare manifestation of a relatively rare disease.

\section{REFERENCES}

FERNANDES, W.R. et al. Colelitíase em eqüinos. Veterinária Notícias, v.7, p.129-133, 2001.

GERROS, T.C. et al. Choledocholithiasis attributable to a foreign body in a horse. Journal of the American Veterinary Medical Association, v.202, p.301-303, 1993.
JOHNSTON, J.K. et al. Cholelithiasis in horses: ten cases (1982-1986). Journal of the American Veterinary Medical Association, v.194, p.405-409, 1989.

MOENS, Y. Cholelithiasis associated with partial liver atrophy in a horse. Vlaams Diergeneeskd Tijdschr, v.59, p.230233, 1990.

PEEK, S.F.; DIVERS, T.J. Medical treatment of cholangiohepatitis and cholelithiasis in mature horses: 9 cases (1991-1998). Equine Veterinary Journal, v.32, p.301-306, 2000 .

REEF, V.B. et al. Ultrasonographic findings in horses with cholelithiasis: eight cases. Journal of the American Veterinary Medical Association, v.196, p.1836-1840, 1990.

SCHNEIDER, D.A. Cholestasis and biliary calculi in horses. Compendium on Continuing Education for the Practicing Veterinarian, v.19, p.744-754, 1997.

TRAUB, J.L. et al. Surgical removal of choleliths in a horse. Journal of the American Veterinary Medical Association, v.182, 714-716, 1983.

TRAUB, J.L. et al. Cholelithiasis in four horses. Journal of the American Veterinary Medical Association, v.181, 5962, 1982.

VAN DER LUER, R.J.T.; KRONEMAN, J. Three cases of cholelitiasis and biliar fibrosis in the horse. Equine Veterinary Journal, v.14, 251-253, 1982. 